\title{
EDITORIAL COMEMORATIVO
}

Este número merece um editorial comemorativo por dois motivos: Cadernos de Linguagem e Sociedade (Papers on Language and Society) completa 15 anos de publicação e alcança, em 2010, a meta de colocar nas mãos do público leitor o primeiro volume semestral dentro do período esperado. $\mathrm{O}$ esforço de lançar dois números por semestre começou em 2008 - com os volumes 9(1) e 9(2) organizados por Izabel Magalhães - e continua com a nova direção do Comitê Editorial, que levou a cabo a tarefa de organização e publicação dos dois volumes correspondentes ao ano de 2009.

Dos sete artigos de pesquisa, presentes neste volume, quatro textos são enlaçados pelo tema da transdisciplinaridade que, em poucas palavras, concerne ao diálogo profícuo entre saberes oriundos de distintos campos disciplinares. Trata-se de quatro artigos que configuram a resposta concreta de colegas que aceitaram o convite de Izabel Magalhães para uma participação no painel “Transdisciplinaridade e Análise do Discurso na América Latina”, apresentado no VIII Congresso da Associação Latinoamericana de Analistas do Discurso (Aled), em 16 de outubro de 2009, na Universidad Autónoma de Nuevo León, Monterrey, México.

O primeiro artigo - Discurso e identidades: exotismo e domínio violento -, merece destaque especial de leitura, sobretudo, porque traz o nome de Izabel Magalhães, fundadora do periódico Cadernos de Linguagem e Sociedade (1995), a quem dedicamos este número comemorativo.

O segundo texto, Empoderamiento y calidad de atención en salud, configura a colaboração da pesquisadora chilena Leda Berardi. Em seguida, Miradas cruzadas hacia la pobreza desde uma perspectiva crítica transdiciplinaria é assinado por mim e por Neyla Graciela Pardo Abril, professora e investigadora da Universidade da Colômbia. O artigo ilustra a interação de pesquisas que desenvolvemos dentro da Rede Latinoamericana de Estudos do Discurso sobre pobreza (REDLAD), do qual faz parte também Maria José Coracini 
(UNICAMP), pesquisadora que assina o quarto artigo, intitulado "Transdisciplinaridade e análise de discurso: migrantes em situação de rua”.

Maria Laura Pardo Gil, uma das fundadoras da REDLAD, envia da Argentina o artigo "La teoria de la Tonalización y la de Valorización: dos teorias complementarias”. A autora sugere que, apesar de distantes tanto do ponto de vista espacial como cultural, a aproximação das duas propostas teóricas beneficia a ambas e, o que mais cabe destacar, representa uma contribuição para pesquisadores/ as que se dedicam a fenômenos linguístico-discursivos pertinentes a três categorias que se entrecruzam, conhecidas como "avaliativas", "apreciativas" e de "tonalização".

O sexto artigo, "Mídia e trabalho infantil: cultura, representação e discurso", marca a presença do centro-oeste brasileiro. Leva a assinatura de Vânia Maria Lescano Guerra em parceria com Rosemere de Almeida Aguerro, ambas da Universidade Federal de Mato Grosso do Sul (UFMS). As autoras, embora seguindo por caminhos teóricos diferentes de Viviane Melo Resende, que assina o sétimo artigo, "A negociação de significados em uma reunião do Movimento Nacional de Meninos e Meninas de Rua”, tangenciam questões empíricas muito próximas, associadas a duas etapas anteriores à vida adulta: a infância e a adolescência. Enquanto Resende $(\mathrm{UnB})$ dedica-se à análise da negociação do significado de 'protagonismo juvenil', baseando-se nos pressupostos teóricos e metodológicos da Análise do Discurso Crítica (ADC), Guerra e Aguerro ancoram-se nos estudos foucaultianos, bem como nas noções dos Estudos Culturais, para a análise da construção do discurso da mídia sobre o trabalho infantil.

O texto seguinte leva a assinatura de um convidado especial, que integra há muitos anos o Conselho Consultivo de Linguagem e Sociedade. Trata-se de Jacob Mey, professor Emérito da Universidade de Odense (Dinamarca). O ensaio Current issues in Societal Pragmatics (Questões correntes na Pragmática Social) aponta a necessidade de uma consciência renovada do ser humano no que concerne ao uso da linguagem. Com base em dois casos reais (um no 
Brasil e outro na India), Mey discute sua pragmática social e sugere caminhos para o que ele denomina como uma "ecologia da linguagem humana”. A colaboração do Professor Mey representa mais uma presença amiga a homenagear Izabel Magalhães.

Somam-se às colaborações presentes neste volume três resenhas elaboradas, respectivamente, por Elizabeth Fávero (UFMS), Veralucia Guimarães de Souza (UFMT) e Sinara Bertholdo de Andrade (UEGFormosa).

“Tomara, mas tomara mesmo" que a leitura seja agradável e produtiva para o público em geral e para tod@s que, de modo particular, compartilham a torcida pela "apreciação positiva" e a "valorização" tão almejada, em termos de classificação e reconhecimento científico, para Cadernos de Linguagem e Sociedade.

Denize Elena Garcia da Silva

Comissão Editorial

Brasília, junho de 2010 